\title{
Health and the Value of Inheritance
}

The meanings surrounding a rare genetic disease

Waleska de Araújo Aureliano

State University of Rio de Janeiro (UERJ)

\begin{abstract}
In this article I explore the meanings acquired by the notion of 'genetic inheritance' for families in Rio de Janeiro affected by a rare hereditary disorder, Machado-Joseph disease. My analysis examines three points: 1) how experience of the disease was thematized in the family prior to knowledge of its genetic and hereditary origin; 2) how knowledge of genetics affected the family's perception of their health and reproduction through the notion of risk contained in medical explanations; 3) finally, I problematize the meanings of 'hope,' a sentiment frequently cited by people with the disease and their descendants. Notably, despite the high value attributed to science and 'medical progress,' the use of certain biotechnologies is not always seen as positive or capable of enabling choices and actions in response to a rare disease. Notions of risk, responsibility and hope thus acquire singular contours for managing life and the continuity of the family.
\end{abstract}

Keywords: Rare Genetic Disease; Machado-Joseph Disease; Genetic Inheritance; Family and Kinship; Hope.

\section{Resumo}

Neste artigo analiso os significados que a noção de "herança genética" adquire para famílias cariocas afetadas por uma enfermidade rara e hereditária, a Doença de Machado Joseph. Considero na análise três pontos: 1) como a experiência da doença foi tematizada na família antes de se saber sua origem genética e hereditária; 2) como o conhecimento em genética afetou a percepção da família sobre sua saúde e reprodução a partir da noção de risco 
apresentada pelas explicações médicas; 3) por fim, problematizo os significados da "esperança", sentimento frequentemente mencionado nas narrativas dos sujeitos afetados e seus descendentes. Percebe-se que, apesar da valorização da ciência e dos "avanços da medicina", o uso de certas biotecnologias nem sempre é encarado como positivo ou capaz de permitir escolhas e ações diante de uma doença rara. Assim, noções de risco, responsabilidade e esperança adquirem contornos particulares para gestão da vida e a continuidade da família.

Palavras-chave: Doença Genética Rara; Doença de Machado-Joseph; Herança Genética; Família e Parentesco; Esperança. 


\section{Health and the Value of Inheritance}

The meanings surrounding a rare genetic disease

Waleska de Araújo Aureliano

\section{Introduction}

In November 2013, the Inclusion Program on Brazil's TV Senado channel was dedicated to the subject of rare diseases. ${ }^{1}$ The program showed a family with various generations affected by a serious form of ataxia. ${ }^{2}$ An older man with a mild manifestation of the disease's symptoms accompanied his 24-year old daughter. She had already become blind due to the complications caused by the ataxia and used a walking frame to move about. Her own eightyear old daughter had also inherited the genetic mutation and presented the worst symptoms among all the family members: she was blind and in a vegetative state, breathing and being fed via medical equipment. The family had filed a lawsuit for the state to provide a mini-ICU and nursing care in their home. The child's grandmother, who was responsible for looking after her, along with the nurse, recognized that the disease had no cure, was nonetheless hopeful that some kind of treatment would be discovered soon.

The same television program showed the day-to-day care for Fernanda, a 15-year old adolescent diagnosed with cystic fibrosis (CF). ${ }^{3}$ Though the disease is genetic and serious, Fernanda declared that she wanted to raise her own family, since "if my child are born with CF, I shall know how to treat the disease. And I'm hopeful that in the near future they will be a cure for the disease, because some mutations already have a cure, though not mine yet."

\footnotetext{
1 TV Senado is a public television channel broadcasting events and activities promoted by Brazil's Federal Senate.

2 Ataxia is the name given to a series of degenerative neurological diseases that mainly affect movement and speech. Though various acquired forms of the disease exist, the majority are genetic and hereditary in origin.

$3 \mathrm{CF}$, also known as mucoviscidosis, causes breathing difficulties, digestive tract problems, infertility and frequent respiratory infections. People with the disorder have a life expectancy of around 40 years: cause of death is generally respiratory failure.
} 
Despite winning a court decision that obliged the State to pay for a series of medications needed to treat his daughter, Fernanda's father claimed that he spent around $\mathrm{R} \$ 8,000$ a month (equivalent to $U \$ 3,400$ at the time) on other medications not covered by the legal ruling.

The two cases raise a number of the questions surrounding the experiences of Brazilian families affected by rare genetic and hereditary disorders currently without cure or treatment. One of them is the perceived limitations of the medical knowledge available concerning these diseases and the care provided in both the public and private health systems. This situation has led to a rise in healthcare-related lawsuits in Brazil and prompted discussions on the advances made in universalizing Brazil's public health system and its limitations (Biehl \& Petryna 2011, Biehl et al. 2009, Diniz 2009).

A second issue to emerge from the TV program is the families' varying perception of two notions central to studies of genetic and hereditary diseases in both the biomedical sciences and the social sciences: the ideas of genetic risk and self-responsibility (Rose 2013, Finkler 2003). Contrary to what some studies predict (Finkler 2001), knowledge of genetics does not necessarily alter significantly people's perception of risk when it comes to family reproduction and the construction of kinship.

Moreover, the forms of self-care that emerge in the Brazilian context appear more closely bound to a conception of 'fighting' to ensure that good health care is mandatorily provided by the State, rather than being necessarily related to the idea of autonomy or choice, as observed by researchers studying Euro-American contexts (Rose 2013). Hence "taking responsibility for your own health" may mean anything from everyday care for a body debilitated by disease to the demand for public health care policies, which may be collective or individual, as in the case of the lawsuits for the State to provide specific medications.

Finally, in practically all the interviews recorded for the TV program, hope figured as a feeling that needs to be nurtured if one is to continue living in the face of incurable diseases. This hope is an element necessary both for the construction of the present and for imagining future possibilities involving the sick person and his or her family. It rests on the 'scientific prospects' for a cure, though this does not always signify the kind of political engagement with the field of science identified in other analyses (Rose 2013, 
Novas 2006, Epstein 1996). Rather, this hope seems to be directed towards an everyday practice and a moral project capable of making life possible in the present, even though the future remains uncertain (Mattingly 2010). In this process, science emerges as an agent capable of 'producing hope.'

Setting out from this set of questions, in this article I shall examine the ideas surrounding the notion of 'genetic inheritance' for families in Rio de Janeiro affected by a rare and hereditary disorder, Machado-Joseph disease (MJD), exploring the different meanings attached to genetic technologies. This aim in mind, I consider three points: 1) how experience of the disease was thematized in the family prior to knowledge of its genetic and hereditary origin; 2) how knowledge of genetics affected the family's perception of their health and reproduction through the notion of risk contained in medical explanations; 3) finally, I problematize the meanings of 'hope,' a sentiment frequently mentioned in the narratives of people with the disease and their descendants.

The data analysed here results from on-going research with families with a history of MJD living in the city of Rio de Janeiro. ${ }^{4}$ Contact with these families was established in December 2012 with the creation of an association for people from Rio de Janeiro state living with acquired and hereditary ataxias and their families.

MJD is one of the inherited forms of ataxia and was first identified in the medical literature in the 1970s, though it was only in the 1990s that it was identified genetically. In Brazil it is the most frequent form of hereditary ataxia (Jardim et al. 2001, Lopes-Cendes et al. 1997). 5 There is no treatment or control for MJD. Therapeutic interventions like physiotherapy and speech therapy aim to minimize the effects of the disease, which eventually leads to bodily paralysis. Generally speaking MJD manifests in adult life around the age of $40 .{ }^{6}$ People affected can live for decades while the disease evolves before dying not from the disease itself but from secondary complications.

\footnotetext{
4 I thank CNPq for the postdoctoral award that enabled this research to be carried out at the Museu Nacional/ Federal University of Rio de Janeiro (2012-2014).

5 The principal symptoms of MJD are loss of balance, muscular paralysis, speech problems, difficulty swallowing and double vision.

6 In some cases the disease may begin at the end of adolescence, and very rarely during childhood. The age when the disease manifests may be connected to the severity of the genetic mutation, aggravated by the higher number of repetitions of the CAG code on the ATXN3 gene, located on chromosome 14 (http://www.ncbi.nlm. nih.gov/books/NBK1196/, accessed on 07/10/2013).
} 
As far as I know, there is just one work in anthropology that tackles the subject of MJD in Brazil, namely the book by João Biehl (2005). His analysis focuses on the story of a woman abandoned in a 'geriatric house' in the south of the country, labelled mad by doctors and her family alike. Exploring what he calls "social zones of abandonment," Biehl takes the life history of this woman as the basis for analysing the complex network formed between the family, medicine, the State and the economy, which culminated in her complete social exclusion following a psychiatric diagnosis for someone who, in fact, suffered from a rare hereditary disease. However, the author does not analyse how the technologies and medical discourses involving genetics have been received in Brazil, nor their impact on the construction of kinship, which are my objectives here.

The article divides into four parts. In the first I describe the current scenario of rare diseases in Brazil and the policies being developed for sufferers. Next I explore some of the ideas that emerged in anthropology at the end of the twentieth century and the beginning of the twenty-first to explore the knowledge generated by the field of genetics. My survey of this topic is not intended as a theoretical review: it merely serves to introduce a number of concepts important to studying the possibilities and limitations of their utilization in the diverse cultural contexts into which genetics has penetrated. Lastly in the final two parts of the text I turn to my ethnographic data to analyse how my interlocutors manage notions of risk, responsibility and hope as part of their experience of a rare disease in the family.

\section{Rare Diseases in Brazil}

The World Health Organisation classifies a disease as rare when it affects 65 in every 100,000 people. Despite the lack of consensus on the exact figure, estimates suggest that between 6,000 and 8,000 rare diseases exist in the world, $80 \%$ of them genetic in origin, affecting $8 \%$ of the world's population. Data from Brazil's Ministry of Health suggests that between 13 and 15 million of the country's inhabitants have some kind of rare disease.

Most of these diseases are incurable and untreatable, provoke severe states of morbidity and disability, and, in some cases, lead to early death. This reality, allied with the fact that many of these diseases have only recently 
been identified by the medical literature, can have profound impacts on how the individuals involved continue to pursue their life projects, relationships and reproductive choices, marked by the idea of 'genetic inheritance.'

Families with a history of rare diseases, each with its own emphases and forms of action, have joined forces politically at global level in search of treatments and health care. In this process, they have built relationships with biomedical, scientific and legal systems and civil society organisations through associations of sufferers of rare diseases and their families (Rose 2013, Akrich et al. 2013, Rabeharisoa et al. 2013, Rabeharisoa et al. 2012, Novas 2006, Rabinow 1999).

In Brazil, the joint action of government, scientists, physicians and associations led to the development of the National Policy for Comprehensive Care of People with Rare Diseases (PNAIPDR), instituted through Directive 199, published in January 2014.7 In 2012 a workgroup was set up by the Ministry of Health to draft this policy. In April 2013, a public consultation was held to hear from other associations not present in the official workgroup. PNAIPDR envisages the creation of medical referral services equipped to provide specialized care to people with rare diseases.

One of the main complaints of families concerns the delays in obtaining a precise diagnosis, the outcome, they argue, of the lack of knowledge among physicians themselves concerning these diseases. The planned referral services would improve this situation by offering more precise and quicker diagnoses. This, in turn, would allow more effective treatments to begin sooner, offering a better quality of life to patients, albeit often only in palliative form since treatment does not always imply control of these diseases.

To achieve these goals, various actions and procedures will need to be created within the National Health System (SUS), including expansion of the list of medications offered, DNA testing and genetic counselling. The challenge now, the associations say, will be to make sure the policy "leaves the drawing board." Since the public health system in Brazil is hierarchized and decentralized, responsibility for introducing the referral services will fall to the states and municipalities, using their existing structure, but receiving a financial input from the federal government.

7 http://bvsms.saude.gov.br/bvs/saudelegis/gm/2014/prto199_30_01_2014.html (accessed on 20/04/2014). 
In this scenario, specialists in medical genetics will be needed to compose the referral service teams and a new question arises: the scarcity of professionals trained in this area in Brazil. The directive initially envisaged that only physicians trained in this speciality would be able to provide genetic counselling. This decision prompted criticisms from non-medical geneticists who claimed that there were insufficient professionals to meet demand. ${ }^{8}$ According to data from the Brazilian Society of Medical Genetics (SBGM), the speciality was recognized in Brazil in 1983. However as recently as 2011 the Federal Council of Medicine (CFM/CREMESP 2011) reported that just 156 medical geneticists are found in Brazil, $85 \%$ of them working in the south and southeast regions of the country.

In Brazil, the majority of the genetic testing and counselling services are located in university hospitals, public hospitals located in large urban centres and blood donation referral centres (Diniz \& Guedes 2005). A portion of the services offered in public centres for genetic medicine are intended for investigating genetic traits potentially responsible for chronic and degenerative diseases that can be transmitted to a couple's descendants, looking to provide advice towards their reproductive decisions. ${ }^{9}$

According to a report in a national publication, ${ }^{10}$ around two thousand people undergo genetic testing each year in Brazil. At the time of this report (November 2009), the price of the tests in private clinics varied between R\$ 600 and $\mathrm{R} \$ 15,000$, making them accessible to only a small section of the country's population. In 2008, the National Supplementary Health Agency (ANS) included genetic testing and counselling in the list of procedures to be covered by private health plans. According to the SBGM, ${ }^{11}$ these initiatives are expanding the Brazilian population's democratic access to biotechnologies

8 For criticisms from non-medical geneticists on the guidelines of Directive 199, see: http:/|www.ib.usp.br/ mais-noticias/725-portaria-exclui-geneticistas.html (accessed on 25/03/2014). According to the president of one patient association that played an active role in constructing PNAIPDR, this ruling had been revoked and nonmedical geneticists would be able to provide genetic counselling following appropriate training.

9 This is the case, for example, of the Department of Medical Genetics at the Fernandes Figueira Institute, run by the Oswaldo Cruz Foundation (FIOCRUZ), which has a genetic testing and counselling program aimed at couples and expectant mothers with histories of genetic disease in their families or who have had children with congenital diseases (source: http://www.fiocruz.br/portaliff/cgi/cgilua.exe/sys/start.htm?infoid=166\&sid=75, accessed on 25/02/2012).

10 http://veja.abril.com.br/251109/testamento-dentro-cada-um-p-104.shtml (accessed on 08/03/2012).

11 http://www.sbgm.org.br (accessed on 25/02/2012). 
developed in the genetics area. In December 2013, ANS extended the list to include tests for 29 genetic diseases and set guidelines for the procedures already approved since 2008 but that had yet to be covered by the private health plans. ${ }^{12}$ Nevertheless, hundreds of rare diseases still remain uncovered by these initiatives.

What we can observe in the Brazilian context is that interventions requiring specialized knowledge in medical genetics depend on a coordination of the public and private sectors, similar to what already occurs with other diseases. People face difficulties in accessing diagnostic tests: at present, while PNAIPDR is still waiting to be implemented, these are very often obtained through networks of collaboration between professionals and researchers based in public universities. The Porto Alegre Polyclinic Hospital, for example, conducts tests for patients of university hospitals in a number of Brazilian states, employing resources and professional staff linked to a research project run by the Federal University of Rio Grande do Sul (UFRGS). Financed by the Rio Grande do Sul Research Support Foundation (FAPERGS), the project's main objective is to make the molecular investigation of neurogenetic conditions available for individuals from diverse parts of Brazil, forming a national research network on such diseases. Today eleven hospitals are linked to this network. ${ }^{13}$

In Rio de Janeiro, patients with MJD receiving care at one of the city's university hospitals have successfully obtained genetic tests via this network, which depends on public funding for scientific research in order to be able to continue testing. According to one Rio medical geneticist:

We obtained the tests through the network, it's an exchange, they need research material, we need to assist patients who have spent years searching for this diagnosis. But if funding for the research ends, the tests end too. It's not SUS that conducts the tests.

In this case, groups of patients are invited to visit hospital on the same day in order for a blood sample to be taken and sent to Rio Grande do Sul.

\footnotetext{
12 http://g1.globo.com/bemestar/noticia/2013/12/planos-de-saude-terao-de-cobrir-exames-para-29-doencasgeneticas.html (accessed on 15/12/2013).

13 For more information on the UFRGS Neurogenetic Network, see http://www.ufrgs.br/redeneurogenetica/ (accessed on 09/12/2014).
} 
The hospital lacks the funds to dispatch this material so the patients themselves share the freight costs. It may take several months before the results are ready. However this is how some Rio patients have managed to confirm the diagnosis of a rare and degenerative disease and, furnished with this information, take life-changing decisions such as requesting retirement with a disability pension.

The publication of PNAIPDR aims to transform the present scenario by creating permanent channels for the diagnosis and treatment of rare diseases. It remains to be seen just how and when the policy will be finally introduced into the public health system and the extent of its coverage. It seems likely that due to the variability in the diseases (some of which affect just a few dozen people) and the shortage of trained professionals (such as medical geneticists) just some Brazilian states and municipalities will manage to institute referral centres.

One alternative for care has been to link the initiatives for people suffering from rare diseases to those already formally established for people with physical disabilities, which are more widely disseminated in the country (such as special pensions, free access to public transport, specialized care in the public health system). Unlike someone who is blind, deaf or paraplegic, however, a person suffering from a rare disease does not always find it easy to obtain formal recognition of their disability, especially in the case of diseases that evolve gradually. Hence the situation for people in Brazil living with a rare disease is complex: they face limitations ranging from diagnosis to the lack of treatments or social recognition of their specific problems and needs.

\section{Exploring Concepts and their Possibilities}

In investigating rare diseases we can quickly perceive the interconnections between some of anthropology's canonical themes, such as studies of family and kinship, combined with recent theoretical explorations that emerged at the end of the twentieth century surrounding the new biogenetic technologies, including Rabinow's concept of biosociality (1999) and Lippman's concept of geneticization (1992). Both were developed in the $1990 \mathrm{~s}$ during a period preceding the first public release of the Human Genome Project results. Despite the particularity of each author's approach, Lippman 
and Rabinow pointed to a series of transformations in social relations and the construction of new individual and collective identities, which would later be spurred on by the new genetics. ${ }^{14}$

Other researchers have analysed the development of gene-based biotechnologies and their effects on the construction of family and kinship. Finkler (2000, 2001), for example, argues that these categories have been medicalized following the advent of genomics. In her view, genetic medicine attributes a cultural meaning to genetic transmission that reflects American perceptions of kinship as a biological fact, as studied earlier by Schneider (1980), reinforcing the traditional pattern of the western family.

Finkler conducted her US-based research with healthy people from families with a history of diseases like cancer and with adopted people. Among both groups she observed the adoption of care practices motivated by the idea of 'genetic risk' by people who were otherwise completely healthy: these practices range from the regular use of medical tests to the search for biological parents in order to compile a family clinical history to be presented at medical meetings.

On the other hand, authors like Rose (2013) and Novas (2006) regard the new scenario opened up by genetics as a source of potential revitalization for the social and human sciences. They point to what they interpret as new forms of exercising biopower and creating biopolitics that no longer operate 'top-down' but through feedback loops, connecting patients, associations, scientists, the market, the media and the State.

In Rose's view, our present historical moment has moved away from an earlier period of euphoria over genetics, epitomized by the eugenicist projects of twentieth-century totalitarian states. Contemporary biopolitics necessarily involves the dynamics of choice, autonomy and self-responsibility, and, at the same time, bioeconomic interests aimed not at eliminating individuals or groups but at improving bodies and generating profits. Focusing on advanced liberal societies, Rose claims that we are living in an 'economy of vitality' based on the 'molecular' knowledge of life and its possibilities for

14 Castiel et al. (2006) argue that the terms 'new genetics' and 'genomics' were created to dissociate the recent research in genetics from the eugenicist projects developed under totalitarian regimes. For the authors, "while the old eugenics operated repressively via state authority, modern genomics acts primarily through market mechanisms and uses the language of individual empowerment and the consumer's freedom to choose" (2006: 194). 
exploration, which acquire different meanings for different actors (industry, governments, patients and markets).

Novas (2006), for his part, analyses how patient activism in search of cures or treatments for certain diseases has reconfigured the Foucauldian perspective of biopolitics. Specialists and States are no longer the only agents to define the mechanisms for controlling life. Subjects themselves, sick or otherwise, also conceive of themselves as biological entities and demand adjustments to social policies for promoting the life and well-being of individuals and collectivities.

Novas analysed two cases in the United States where patient associations played a central role in collecting funds and, principally, biological material for the development of research on rare diseases. In this process the human body and its parts were turned into 'bargaining chips' in the patient-scientist relation, forming a biovalue. ${ }^{15}$ Uniting the interests of both is hope, a sentiment evoked to mobilize attempts to discover a cure, necessary to save the lives of some and produce wealth for others.

The discussions opened up by these authors raised some stimulating topics for anthropology, traversing theoretical fields spanning from family and kinship studies and the anthropology of health and medicine to social studies of science and technology, economics and politics. However we also need to pose a question: just how influential is the new genetics in sociocultural and economic contexts where biotechnologies are still largely inaccessible? How does this area of science influence decisions over health, bodily care, reproduction and relationships? Is knowledge of their own genetic condition really becoming a widespread demand among individuals with a family history of serious disease? How are notions like choice, risk, responsibility, 'genetic prudence' and autonomy imagined in contexts distinct to those where the above authors conducted their research - and indeed within these contexts too?

Recent studies have shown that there are limits to the generalized use of concepts such as 'geneticization' and 'biosociality,' even in advanced liberal societies. Gibbon (2004), for example, questions the passivity attributed to

15 The term biovalue was introduced by Waldby (2002) to describe how certain biological materials (blood, tissue, DNA and so on) are transformed into values due to their potential to augment human health and, at the same time, generate economic wealth. 
patients in analyses that overestimate the impact of new genetic technologies on the formation of clinical identities, ignoring the negotiations that inevitably unfold in patient-doctor discussions on the hereditary nature of breast cancer. Lock (2008), in turn, observed that the genetic testing used to assess the risk of developing Alzheimer's disease (AD) is not a major factor for family members with the disease. Family life is perceived to be more important than testing, which is ambiguous and uncertain in terms of establishing risk, meaning that trying to produce a sociability founded on genetic inheritance makes no sense to many people. Lock also observed that the associations between these families centred much more on providing and obtaining guidance on everyday care for people with $\mathrm{AD}$ than on determining the genetic causes of the disease. We need to ask, therefore, whether the new genetics really has transformed family relations, medicalizing kinship - or has it merely facilitated the shifts between the already existing physical, moral and affective dimensions of constructing the family?

To explore these questions in more depth, I shall present the ethnographic material collected by myself over an almost two-year period with families affected by Machado-Joseph disease living in Rio de Janeiro. This group represents just one tiny sample from a vast and diverse population with rare diseases. I approach my analysis, therefore, as a case study that cannot be generalized but which is useful to the development of new questions capable of shedding some light on the complex multiplicity formed by the universe of people living with rare diseases.

\section{Other Logics for Comprehending Risk and Responsibility}

I begin with the narratives of people with and without symptoms of MJD from two different families, who I shall call the Silva family and the Santos family. Both families originally came from the Rio de Janeiro suburbs, with some members still residing in this region, but with relatives also living in the north and west zones of the city. Though from a working-class background, today the economic conditions of family members would place them among Brazil's urban middle class. The second generation, now aged between 48 and 73 years old, with whom I have had the most contact, and most of whom present symptoms of the disease, were formally employed 
in the public sector (civil or military). Among their own children, the third generation aged between 16 and 43, many have completed higher education, with one of the women being a university professor.

Most members of the two families access health services through a combined use of the public and private systems. Those with health insurance plans and/or who visit private doctors also turn to the SUS for health care. Some use the Rio de Janeiro unit of the Sarah Kubitschek Network, popularly known as 'Rede Sarah,' a complex of hospitals run by the federal government that specializes in neurorehabilitation, offering treatments like physiotherapy and speech therapy to people with ataxia. ${ }^{16}$ However individuals can remain patients of this referral centre for only a set time and, after being discharged, must continue their treatment by themselves, paying specialized professionals.

In both families, ataxia began to be recognized through the condition of the father of those today presenting the same symptoms. The recollection of the father who had slurred speech, walked unsteadily and ended up in a wheelchair emerges as the strongest early memory of the disease, subsequently observable in other members of the paternal family. Both families refer to the suffering of the father (or the grandfather for those in the third generation) being compounded by his condition going undiagnosed.

For two cousins from the Silva family, married for more than 40 years, who I shall call Ana and Otto, the earliest memory of the disease relates to their fathers, albeit in different ways: Ana, symptomless, recognizes that her father had MJD, though no precise diagnosis was obtained before his death. Otto, who has manifested evolving symptoms of the disease for 20 years, initially repeated his father's explanation that his paralysis had been caused by an accident.

Both also evoke the image of the paternal grandmother who 'died paralytic,' but the association with the same disease as their fathers was not immediately made at the time. Temporal and spatial distance seem to be a key element influencing the lack of connection made between the disease of their two fathers, witnessed first-hand, and the illness of their grandmother, who lived in another city and 'died an old woman' when they were still children. According to Ana:

16 See http://www.sarah.br/ 
The people there from the Northeast said grandma so-an-so died paralytic, but we had no idea what it was, what that was, that it came from the family. Because this disease came from this grandma of mine.

In the absence of any conclusive diagnosis and given the advanced age at which the disease manifested and worsened in the grandmother and both fathers, associations 'age-related diseases' were not discarded. Other explanations were also cogitated, such as an accident in the case of Otto's father, or even a 'weakness' in the case of Ana's father who for a long time, according to one of her sisters, was assumed to be a heavy drinker when the symptoms first manifested, not only by neighbours, but by his own family. ${ }^{17}$

The Silva family discovered that the disease was genetic and hereditary after one of Ana's sisters, manifesting symptoms around the age of 40, decided to take a DNA test. Since the test in question was not performed in Brazil at the time, her sample was sent to the United States. The identification of her disease paved the way for another two siblings from the Silva family to seek out the tests when they too began to show symptoms, primarily to explain their problems at work and retire with a disability pension. The first test was conducted in a private laboratory in Minas Gerais and the result proved negative. This provided leeway for their work colleagues to claim that the siblings were 'somatizing' their sister's disease and their problem was 'just psychological.' However their symptoms worsened and they sought out a second test, this time at a laboratory of the University of São Paulo. The result was positive and today they are suing the laboratory in Minas Gerais.

In the Santos family too, it is the father of those manifesting symptoms today who is mentioned first. The proximity with the aunts and uncles, siblings and cousins - almost all of them living in the same city, unlike the Silva's who have close relatives living in other states - made it clear, though, that the disease was some kind of 'family problem.' But until members of the second generation were diagnosed, nobody knew for certain what it was. Describing his father, Miguel, an MJD sufferer, said:

At the time the disease wasn't known, my father was being treated by Doctor $\mathrm{X}$ here in Rio, and the latter told him: 'Look, you have an incurable degenerative disease,' but he didn't mention its name and my father just couldn't accept it,

17 The staggering and slurred speech mean that many of those suffering from MJD are mistakenly taken to be drunk. 
the fact he didn't know what it was, he couldn't accept it. He just felt himself fading away.

For his niece, who I shall call Sofia, who had no symptoms of the disease, the image of the grandfather is present, but so too the image of a great aunt who in fact raised her mother, since the latter was left an orphan at the age of 2 (her mother is Miguel's half-sister and also shows symptoms of the disease). Describing her great aunt, she said:

She hauled herself about. Of all those I saw, she was the worst. She couldn't walk, she dragged her feet until one day she fell in the bathroom, she spent the whole day in the shower.

Miguel and Sofia both refer to the reluctance of the father (grandfather) and aunt to use a wheelchair: this would have been the social concretization of the disability caused by the disease. According to Miguel, his father died when he was 73: "But because he let himself go [...]. He didn't do any physical exercise, he wouldn't agree to using a walking stick, he refused to use a wheelchair, he didn't accept anything."

The disease was first identified among the Santos family when a cousin living in Germany began to present symptoms around the age of 50 and took a genetic test in 2003. On the advice of her doctors, she compiled a dossier on MJD and sent it to all her relatives in Brazil. The family's response was to ignore the document. Miguel, then without any symptoms of the disease, told me:

I didn't pay any notice, I didn't want to know, who kept it was my sister [Sofia's mother], I didn't want to know, I don't want to know about any disease.

Sofia meanwhile said that:

In 2003 I was beginning my master's course, starting to teach classes, it was tumultuous time, there were so many things in my head, I didn't take time to read the dossier. My cousin deluged us with this topic, she wanted us to study it, she wanted me to investigate more deeply, but nobody did, nobody would listen to her.

However the diagnosis sent by the cousin did at least put a name to the disease, even if the family made no attempt to learn more. Those who developed symptoms after this dossier knew what disease they had and were able 
to tell the doctors. Members of the third generation, still without symptoms, did not seek out predictive tests or genetic counselling.

The situation experienced in the Santos family invites comparison with Konrad's analysis (2003) of diagnostic revelations, the construction of prognoses for genetic diseases and their repercussions on the family. Konrad worked with people 'at risk' of having inherited the gene for Huntington's disease (HD) ${ }^{18}$ and explored the moral obligation that surfaces in the management of genetic information: who to tell and who not to tell? This produces an intense moral dilemma involving the disclosure or secrecy about the genetic condition, which permeates from the medical sphere into the domain of the family. The situation elicits an important discussion on ethics, personal rights, duty of care to the other, and how family relations are impacted by genetic information.

On the other hand, revealing a personal diagnosis to other family members morally compels them to learn more about their own genetic condition, something not always welcomed, especially among kin without any symptoms, who, like Sofia and her uncle, "don't want to know about disease."

Sofia, for example, once told me that she has no wish to take the predictive test to discover if she carries the MJD gene because she thinks that "the mind constructs everything in us." In her view, being diagnosed while still young could mentally accelerate the physical manifestations of the disease. ${ }^{19}$ Her biggest concern is the wish to have a child. Though she recognizes the health problem in the family, its hereditary nature and its complications, Sofia says that she has never thought about not having a child. However this does not mean that she did not make precise plans for her life, taking into account the risk of genetic inheritance in her family. For example, she waited until she had passed a public sector recruitment exam before trying to become pregnant:

18 A rare genetic disease that affects the central nervous system and whose typical neurological manifestations are involuntary movements, intellectual deterioration and a variety of psychiatric disturbances.

19 This concern with the mind-body relation, and the capacity of the former to affect the latter, is relatively common among people affected by rare diseases that attack the neurological system. Indeed it appears among health professionals too, as illustrated by a remark made by one psychologist in a book intended for people with MJD. There she claims that "it should be stressed that the gradual physical incapacities present in MachadoJoseph disease and/or in other types of ataxia generate and/or is generated automatically by negative emotional responses" (Abrantes 2009: 134). The author adds that failure to give new meaning to everyday life and relations after onset of the disease may trigger depressive and anxious mental disorders and thereby "aggravate the symptoms and quicken the disease's evolution" (ibid: 135). 
I always thought that I had to have a job first, a good job, that would allow me to live, and if the disease appeared, one that would enable me to pay for a health plan.

Ana and Otto, who are first-degree cousins, always joke that had they known about MJD earlier they would never have been 'mad enough' to get married: since both of them may have the disease, they recognize that the chance of having sick children will be higher. When I asked them about their children, two adult men now in their forties, each with a daughter of his own, and whether they have displayed any concern about having inherited the MJD gene, Ana replied that all her family are opposed to "this testing thing." They argue that having a genetic disease "is like an electronic device that comes out of the factory with a defect and is irreparable." For them, while there is no cure or treatment for MJD, there is no point learning about your genetic condition in advance. ${ }^{20}$

The transmission of genes to grandchildren is not an issue among either family. The daughters-in-law of Ana and Otto know about the genetic condition in the family, they say, just like Sofia's husband who has seen the evolution of the disease in his mother-in-law and other relatives. The opinion among both families is that if the children are already born and out in the world, they should live their lives as fully as possible, including having children and raising their own families. Ana, for instance, remarked:

That's how we think. I think that if the Lord [God] has not yet given us a problem with them, if one day he does so, we've already reaped the reward: they were born, they've already started their own family, they've already made their own way in life, both of them. I think it would be much worse to have a [sick] child who hasn't even began living.

Miguel, father of three daughters, says there is no point spending time worrying about the disease and discourages his daughters from doing so:

20 This view is frequently encountered among descendants of people with rare hereditary diseases without prospect of cure or treatment. Guedes \& Diniz (2009) cite research showing that between $80 \%$ and $85 \%$ of individuals at risk of developing Huntington's disease decide not to submit to predictive genetic testing. However, the reasons behind this refusal are diverse, ranging from the fear of receiving a positive diagnosis and not knowing how to respond, to encountering future problems with health insurance companies should this information ever reach them. 
If they're already born, they're already here, there's nothing to be done, they just have to live their lives and not think about disease.

"Living their lives" includes starting their own family, embarking on a professional career and obtaining financial independence, all factors whose attainment is seen to justify downplaying the genetic issue present in the family.

Rather than analysing the percentages, statistics, genograms or longterm physical consequences, my interlocutors thus far seem keener to evaluate the kind of life still possible with the disease. The close relationship with parents, aunts, uncles and cousins who have developed MJD but previously had a professional career or still work today, who can drive even though they become unsteady on their feet, who use computers when they can longer hold a pen, who had time to raise children before they became ill - all of this is taken into account when evaluating predictive genetic testing and the desire to have children or not.

In this sense, the age at which the disease first manifests has an important role in the way in which it is perceived by the members of the two families. Its late evolution and the gradual limitations that do not completely impede some activities from being performed, such as driving or small household tasks, though taken as undesirable may also be comprehended as a tolerable addition to the ('natural') process of aging. Becoming paralytic at the age of 70 , after having raised children or had a career, seems less serious than having a career interrupted while still young or being unable to have children and raise them, as becomes clear in Ana's remarks.

However this does not mean that my interlocutors, whether with or without MJD, see aging as a stage of inevitable dependency, decrepitude or disability. On the contrary, even those of the senior generation with physical symptoms of the disease and the limitations it imposes do not live with their children. Ana and Otto, for example, aged 64 and 73 respectively, live alone in an apartment. Their children visit regularly, but the couple insist on maintaining their independence, travelling by subway or taxi to association meetings or medical consultations.

Sofia's mother also lives alone with her husband. In 2012 he had a stroke that left him paralysed on one side of his body. Using a walking frame to move about, Sofia receives help from a nurse during the day, but says that 
after 5p.m. "it's all up to me." In her case too, her children are in frequent contact, but she says "each of them has their own life."

This perceived independence, even in the face of the disease and old age, is something Sofia highlights too as a reason for not fearing her genetic inheritance. As well as her own parents, she mentions her parents-in-law, both aged over 80 , who have had other serious illnesses like cancer and yet still live alone. In contrast, as her uncle Miguel recalls, her father died sooner because he "let himself go," failing to do any physical exercise, something he himself practices regularly to minimize the disease's symptoms and remain independent for longer.

In both these families, therefore, age emerges as an important factor in how they evaluate the meaning of the disease over the course of life. Its manifestation almost always around the age of 40 is perceived to allow the family to reproduce or the person to plan their professional career.

This helps explains why Sofia waited to establish herself professionally by passing a public sector recruitment exam before attempting to become pregnant. She was well aware that, were she to have inherited the MJD gene, her financial independence would be hugely important, especially in terms of possessing the material conditions to care for herself and her family. Her refusal to take the predictive test does not imply a complete disregard for the possibility that she or her descendants may have the disease: it just means that other values shape her choices and her projects.

Taking tests to confirm the disease becomes important for members of the two families when they begin to display symptoms and need a definitive diagnosis in order to retire, justify their work problems and forced absences, and avoid negative comments, such as the suspicion that they are alcoholic or that they are 'somatizing' a relative's disease.

Miguel, for example, was in the armed forces. During the first years of manifestation of MJD he tried to hide the symptoms and developed strategies to avoid job-related events that would make people suspect he was unwell, or in the best case scenario, that he was drunk, an impression admitted by some colleagues after he left. Only once he had the test results in his hands, five years after the first symptoms appeared, did he finally speak about the problem to his colleagues and immediately retired from work: 
Had I said before [the test when the symptoms were milder] they would have said I was shirking, because I didn't look like I had any kind of disease [...] Had I gone about telling everyone I had the disease, I would have been labelled a shirker.

In these two families at least, therefore, we can observe that the demand for genetic testing is informed by different factors: for those who have symptoms, the test confirmation can resolve various sociorelational issues, such as the need to prove their genetic condition to other people and legitimize their leave from work, removing the stigma of being seen as a drunk or a 'shirker' from their job. For those not presenting any symptoms, the test is seen as merely a way of anticipating the suffering and anguish of a positive result, and even quickening the disease's development by making the person spend "the rest of their life thinking about this," rather than a way of planning life or enabling reproductive choices.

MJD's symptoms are expressed in various degrees of severity. Several of my interlocutors, with different ages and different periods of manifestations, still drive cars and perform other activities that prevent them from being classed as disabled. Unlike other degenerative and hereditary neurological diseases, MJD does not affect cognition. These factors are taken into account when people refuse to take the predictive tests or reject the idea that they cannot or should not have children. As we saw in Ana's remarks, people argue that by the time the disease manifests, the person may have already lived a full life, a cycle deemed complete when they raise their own family and obtain financial stability.

This does not mean that the families are unconcerned with the risk and seriousness of the disease and its effects, or that they fail to realize there is a risk. They simply conceive this risk in another form, taking other variables into account, such as the potential degree of independence the person can achieve and the fact that the disease manifests later on in life, demonstrating that the perception of this risk is mediated by each person's experience of the disease and operates through affective, moral and relational logics, not only the logic of health.

Obviously there are contrary cases of people highly concerned with the fate of their potential offspring and thus severely question whether they should have children. For these people, in vitro fertilization with a preimplantation genetic diagnosis (IVF-PGD) has been offered as an alternative 
possibility for those already diagnosed with the disease, and those who do not want to know their genetic condition, to have children free of the disease. In this technique various embryos are created through IVF, a cell is removed from each to test whether or not it is free of genetic mutation and, therefore, suitable for implantation. ${ }^{21}$ However this biotechnology-based choice runs up against various obstacles. One is the high cost of this procedure, unavailable through Brazil's public health system, meaning that it can only be obtained via private clinics. In addition, as in every IVF process, the rate of successful pregnancies per attempt is still low, around $30 \%$.

At an event I attended in 2012, in Rio de Janeiro, which brought together people with movement disorders, including people with ataxia, IVF-PGD was mentioned as an option by women with MJD or who were daughters of sufferers. None of them took part in the association formed later the same year. They wanted to know from the physicians present at the meeting whether the technique could be requested through the courts, given that it is not offered by the National Health System (SUS). In a document sent by the Union of Relatives and Friends of Sufferers of Huntington's Disease to the president of Brazil's Federal Supreme Court in 2009, IVF-PGD was listed as a necessity for families affected by with this disease and that it should be offered by the SUS.

At one of the association meetings, the son of a man with MJD - a young man in his early twenties who I shall call Pedro - announced that he wanted to take the predictive test to discover whether he has inherited the genetic mutation for the disease from his father. If so, Pedro said that he will try to have children while he is still young, before the first symptoms of the disease appear. He argued that:

If I wait to have children when I'm 35 and start to manifest the disease at 40 , like my dad, when my child is 15 years old I won't even be able to drive him to a party any longer.

I asked him whether he knew about the IVF-PGD technique and he replied yes, but he did not intend to use the procedure because of the considerable expensive and the uncertain outcome. Knowing whether he could develop the disease would not help him decide whether to have children or not but when to have them.

21 For an ethnographic analysis of pre-implant genetic testing, see Franklin \& Roberts (2006). 
Depending on the person's religious views, this ability to choose may also be problematized. As one of my interlocutors, a spiritist, asked: "Who am I to choose who will be born or not? I don't know if I would choose like that." Religious values heavily influence how this technique is comprehended and explain why it was removed from the list of procedures set to be introduced into the SUS by PNAIPDR. As the president of an association involved in drafting the latter policy told me at one event, many members of the Ministry of Health workgroup considered IVF-PGD a viable form of containing the course of the disease in vulnerable families. However the technique was not included under the argument that it would undoubtedly be targeted by conservative religious groups, hindering or delaying approval of the policy.

More in-depth analyses of families with rare and hereditary diseases are needed in order to observe in what way some social markers of difference, such as religion, gender and age, may be related to perceptions of the family and reproduction, and to biomedical technologies and their uses. My intention at this point is to highlight this variability in perceptions, though aware that a broader study with more families is needed to evaluate the significance and impact of these social markers of difference on the apprehension of genetic knowledge and its uses in Brazil. In so doing I wish to avoid reducing this complexity to a purely economic or structural question of a lack of access to such technologies.

The economic dimension is undoubtedly important and itself a social marker to be analysed, but moral and practical questions also form part of the perceptions and actions of individuals at risk of developing a rare disease. Sofia, for example, after learning about IVF-PGD, went to a clinic specialized in human reproduction and the last time we spoke was waiting for the results of some exams before talking to the specialist again. Meanwhile she continued her attempt to become pregnant "via the traditional method." In other words, she did not discount using IVF-PGD, but she did not want to limit her possibilities to a technique that possesses a high degree of uncertainty in terms of achieving a pregnancy.

The data obtained from these families and from the testimonies of people with other forms of rare and hereditary diseases on the internet and in books leads me to question, in part, Finkler's claim (2001) that biogenetics is reshaping kinship relations previously based on honour and the sharing of beliefs, values and ways of being through the gene's substantiality. What 
I have observed, along with other ethnographic studies (Lock 2008, Weiner 2011, Chilibeck et al. 2011), is that although genetics is indeed extremely important, it has not become a determinant factor in the construction of projects related to the family and its reproduction. Values associated with individual and professional autonomy, the perception of different ages and their phases over the course of life, as well as the affective relations between kin with and without the disease, all have a significant impact on how MJD is perceived and responded to by asymptomatic people.

I concur with Chilibeck et al. (2011) when they argue that genetic knowledge and the use of various biotechnologies has not led to a universal 'geneticization' of individual or family identities. On the contrary, the experience of disease in the family may actually produce a 'familiarization of genetics' (ibid: 1771). Genes are reinterpreted in light of family history, rather than family history being radically modified through genetics.

To repeat my earlier point: this does not imply ignorance of the risk, limitations and consequences of a rare disease, but the attribution of other meanings to these elements as part of the process of making decisions and building life projects. In this process, hope emerges as a moral feeling capable of opening up possibilities in response to the uncertainties of the future and, simultaneously, continuing life in the present.

\section{Hope in the Era of Genomics}

Good et al. (1990) produced one of the first analyses on hope in the health field. The authors focused on how this feeling evolves from the revelation of a diagnosis to the adherence to treatment plans, including as a source of motivation for physicians working with people with incurable or untreatable diseases. How do people engender care and sustain the willingness of others and themselves to continue in a scenario offering few resources to alleviate suffering?

This perspective in mind, hope can be interpreted as a moral project capable of engendering life in the present in situations involving extreme pain and suffering, as Mattingly (2010) explores in her study of AfroAmerican families with children suffering from serious and disabling diseases. The author focuses on hope as a critical dimension of the clinical encounter, negotiated between the families and their sick children and the 
physicians who are also confused about how to provide care to patients with no prospect of cure in a health system as unequal as America's. Consequently, she argues that hope is not linear: it is constructed in direct opposition to the fear and despair that pervade these people's lives and affect their relations. Being hopeful thus amounts to both a practice and a process:

Hope most centrally involves the practice of creating, or trying to create, lives worth living even in the midst of suffering, even with no happy ending in sight. It also involves the struggle to forge new communities of care that span clinical and familial worlds. This is why I have chosen to speak of hope as a practice, rather than simply an emotion or a cultural attitude (2010: 6).

To analyse hope as practice, in her study Mattingly selected a demographic cross-section that included differences in class, race and power. Here she shows how the cultivation of the feeling of hope assumes different proportions depending on whether people have access to an apparatus (medical, social and financial) capable of 'facilitating' the construction of hope - if not for a cure, then at least for a better quality of life. Poor black American have to construct this hope through other meanings and within a specific range of possibilities.

With the advent of the new genetics, hope has been analysed as an element in the political organization of people with serious diseases and their families, including their relationships with medical doctors, researchers and the pharmaceutical industry in what Novas (2006) has called a "political economy of hope. ${ }^{22} \mathrm{He}$ argues that patients and scientists construct a joint field of action impelled by the hope of finding a cure or treatment for rare diseases, bringing relief to the suffering of the sick and profits for the medical-scientific corporations and the drugs industry. The biological material needed to make these hopes concrete is therefore simultaneously a vector of health and wealth.

Less optimistic, Brekke and Sirnes (2011) criticize the literature promoting the concepts of biocitizenship and biosociality for, in their view, trying to rid the new genomic medicine of the ideas of eugenics by using the argument of hope. The authors suggest that this literature presents a unilateral

22 The expression was originally used in the text by Good et. al. (1990), but with a meaning distinct from the one employed by Novas. 
and narrow reading of the discourses involving hope, a feeling whose directional force is not always guided by the possibilities of the future, they say, but by the despair experienced in the present. For Brekke and Sirnes, the contemporary logic of hope annuls the distinction between research and medical treatment. Moreover, the urgency with which certain demands are made by patients is bending the limits of ethics, jeopardizing the principles of bioethics.

Despite the conservative tone permeating the text when it argues for a separation between politics and science (something highly unlikely to exist), one interesting point in Brekke and Sirnes's analysis is their highlighting of the association between hope and despair: specifically, how the possibility of the former depends on emphasizing the latter, a movement that demands the production of specific moralities. This dynamic is observed in the processes of judicialization of health care, just as it was central to the activism surrounding HIV/AIDS (Epstein 1996).

In a recent analysis of the medicalization of hope in the case of terminally ill patients, Menezes (2013) analyses how this feeling has shifted in the modern West from the sphere of Christian suffering to a hedonism centred on physicality. This process transplanted hope from the religious field to the space of science, attributed the capacity to develop infinitely, all the while enhancing the human body and life. Assisted reproductive technology, transplants, new medications and stem cell research all constitute "technologies of hope" (Leibing \& Tournay 2010 apud Menezes 2013) capable of mobilizing people and groups to act in the present in the expectation of a different future.

The feeling of hope is, then, related to an active process, rather than a passive process as might first be thought. It involves a relation between present and future, and, for people with serious diseases, science appears as a horizon through which other futures can be constructed (Novas 2006).

My interlocutors recognize the uncertainty of the future, but this uncertainty can also imply a set of possibilities - and this is where sciences looms large. Although the hope mobilizing these people very stems comes from a religious faith, it is directed towards the achievement of a scientific discovery rather than a miracle. Here it is worth noting how biotechnologies can be legitimized and delegitimized simultaneously in the construction of contemporary ideas of hereditary genetic diseases: while the predictive tests are regarded with distrust due to the present therapeutic limitations of genetic 
medicine, the development of these technologies is valorized as 'advances' toward better knowledge of rare diseases and the discovery of potential treatments or cures in the future. ${ }^{23}$

One of the Silva family with MJD says that she does not believe in a cure for herself, but for her children, should they have the disease:

Today for them, if they have it [MJD], the path is easier, a diagnosis already exists, because just imagine not knowing what condition you've got? Today that's changed: if it happens you already have a path to take and I believe, I'm hopeful, that something will be found in the future, a new drug or something. At USP [the university where she took her genetic test] I became very hopeful, I saw all those heads together studying, I think that something will emerge from there.

The same feeling drives on Sofia, who is also a researcher and academic. She says that, though more or less convinced she has inherited the gene from her mother, she does not want to take the test to know if she has MJD:

I've already decided that if I get the symptoms, I'll manage to find a treatment, that's what I think: by then someone will have discovered something, someone will discover something.

Given the dilemmas permeating the notion of risk, the lack of effective treatment and the difficulties in accessing and using genetic technologies in Brazil, hope functions as a moral value for the construction of everyday life and the projects involving the family.

At the same time, hope is also evoked as a stimulus to collective action, the construction of associations uniting these families ${ }^{24}$ and involving various degrees of engagement and participation. It should be stressed that there is no homogenous disposition among actors to participate in associations in the context under analysis. While for some of my interlocutors the patients association signifies a space to campaign for rights and knowledge relating to their disease, for others it is somewhere to meet their peers, a way of not feeling alone with their disease and of constructing shared forms of confronting it.

23 A similar conception can be found in Lock's work (2008) on families with Alzheimer's.

24 The slogan of one leading Brazilian association for people with Huntington's disease is: "Huntington - it will never degenerate our hope" (http://www.abh.org.br/index.php?option=com_content\&view=article\&id=83\& Itemid $=53$, accessed on 05/09/2012). 
Hence "investing hope in science" does not always involve patients interacting directly with scientists, as Novas describes, although relations may indeed be formed between them. This can be observed in Brazilian associations for patients with rare diseases, which often include collaborators from medical areas and researchers, some having been founded by them or at their suggestion.

In Brazil, though, these patient associations have played a more important role in mediations with the State, campaigning for public health policies that offer care to those suffering from rare diseases, rather than focusing much attention on pushing for more research towards cures (Grudzinski 2013). Here, certainly, the national context and the way in which relations between patients, scientists and the State unfold all play an important role in the way that activism has developed in the country.

For people living with rare and disabling diseases, therefore, hope is not always imbued with the same meanings, neither does it result in the same kinds of action. Its meanings depend on local scenarios and the relations established between diverse actors, the observation of a field of possibilities that favours certain actions rather than others, whether these are individual, everyday actions that need to be managed for life to continue, or those that involve personal or collective projects for the future.

Although evoking a mutual understanding, 'having hope' may represent many things given the uncertainty caused by being diagnosed with a rare hereditary disease. For my interlocutors, these distinct dispositions share the desire to project a future capable of dealing with the issues of the present so that the latter is not paralysed before its time.

\section{Concluding Remarks}

Concepts such as biosociality (Rabinow 1999), biological citizenship (Rose 2013, Petryna 2002), the medicalization of the family and kinship (Finkler 2001, 2000) and geneticization (Lippman 1992) have all been evoked to comprehend, from particular angles, the social processes engendered by the knowledge produced in genetics, usually indicating significant ruptures in the way that subjects conceive themselves individually and collectively. As Rose underlines (2013), these studies have mostly been conducted in countries with advanced liberal economies and health care systems based on 
a logic of choice (Mol 2008), historically recognized forms of social engagement in campaigns for health care (Epstein 1996, Brown et al. 2004) and a strong market conception linked to the development of scientific research (Dumit 2012, Petryna 2011).

These are important factors when we turn to analyse how knowledge in genetics affects and is affected by the social fabric, becoming part (or not) of the conceptions of the body, health and sickness of particular groups in these societies. Hence it is important to note how even in these EuroAmerican centres such categories prove dynamic, revealing the multiplicity of understandings through which they have always been understand and that have not been reduced to genes as some have feared (see Chilibeck et al. 2011, Weiner 2011, Lock 2008, Gibbon 2004).

Given the expansion of biotechnologies and their migration to other national contexts, each with its own particular logic and practices related to health, illness, family, kinship, medical care and scientific research, we need to explore both the possibilities and limitations to using this conceptual framework. Ethnographic research into health in different contexts has shown us that the subjectivities related to disease and the body are neither stable nor homogenous, just as conceptions and uses of medical technologies vary. In this sense, the concepts of biosociality or 'technologies of hope' may be more productive if they remain adaptable to the results of ethnographic observation, which has presented us with distinct nuances for exploring what previously seemed evident, like the definition of genes. This is precisely what I have looked to emphasize in this article by showing how notions of risk, responsibility and hope are constructed and managed by families living with rare hereditary diseases.

These concepts acquire particular meanings, always open to transformation, which may or may not share the meanings produced by the new genetics, allowing shifts capable of responding to everyday life and continuity of the family in a scenario of ever more 'technological advances' that, nonetheless, have yet to pass beyond a horizon of uncertainties.

Received August 30, 2014, approved February 11, 2015

Translated by: David A. Rodgers

Author's e-mail: waurelianorio@gmail.com 


\section{References}

ABRANTES, Mariana. 2009. "A importância da psicologia: do diagnostico ao tratamento." In: Priscila Fonseca (ed.), Superando limites: a vida com ataxia. Rio de Janeiro: Publit Editora. pp. 127-143.

AKRICH, Madeleine; O'DONOVAN, Orla; RABEHARISOA,Vololona. 2013. “The entanglement of scientific and political claims: towards a new form of patients' activism." CSI Working Papers Series, 35: 1-16.

BIEHL, João; PETRYNA, Adriana. 2011. "Bodies of rights and therapeutic markets." Social Research, 78(2): 359-386.

BIEHL, João et al. 2009. "Judicialisation of the right to health in Brazil." The Lancet, 373(9682): 2182-2184.

BIEHL, João. 2005. Vita: life in a zone of social abandonment. Berkeley: University of California Press.

BREKKE, Ole Andreas; SIRNES, Thorvald. 2011. "Biosociality, biocitizenship and the new regime of hope and despair: interpreting 'Portraits of Hope' and the "Mehmet Case."' New Genetics and Society, 30(4): 347-374.

BROWN, Phil et al. 2004. "Embodied health movements: new approaches to social movements in health." Sociology of Health \& Illness, 26(1): 50-80.

CASTIEL, Luis et al. 2006. "Os riscos genômicos e a responsabilidade pessoal em saúde." Rev. Panam. Salud Publica/Pan Am J Public Health, 19(3): 189-197.

CFM/CREMESP. 2011. Demografia médica no Brasil: dados gerais e descrições de desigualdades. Coordinated by Mário Scheffer, Aureliano Biancarelli and Alex Cassenote. São Paulo: Conselho Regional de Medicina do Estado de São Paulo and Conselho Federal de Medicina.

CHILIBECK, Gillian; LOCK, Margaret; SEHDE, Megha. 2011. "Postgenomics, uncertain futures, and the familiarization of susceptibility genes." Social Science \& Medicine, 72(11): 1768-1775.

DINIZ, Debora. 2009. "Judicialização de medicamentos no SUS: memorial ao STF.” Série ANIS, 66: 1-5. Brasilia: Letras Livres.

DINIZ, Debora; GUEDES, Cristiano. 2005. "Confidencialidade, aconselhamento genético e saúde pública: um estudo de caso sobre o traço falciforme." Cad. Saúde Pública, 21(3): 747-755.

DUMIT, Joseph. 2012. Drugs for life: how pharmaceutical companies define our health. Durham and London: Duke University Press.

EPSTEIN, S. 1996. Impure science: AIDS, activism, and the politics of knowledge. Berkeley: University of California Press. 
FINKLER, Kaja. 2003. "Illusion of controlling the future: risk and genetic inheritance." Anthropology and Medicine, 10: 52-70. 2001. "The kin in the gene: the medicalization of family and kinship in American society." Current Anthropology, 42(2): 235-249. . 2000. Experiencing the new genetics: family and kinship on the medical frontier. Pittsburgh: University of Pennsylvania Press.

FRANKLIN, Sarah; ROBERTS, Celia. 2006. Born and made: an ethnography of preimplantation genetic diagnosis. United Kingdom: Princeton University Press.

GIBBON, Sahra. 2004. "Re-examinando a 'genetização': árvores familiares na genética do câncer de mama." Política e Trabalho: Revista de Ciências Sociais, 20: 35-60.

GOOD, Mary-Jo del Vecchio et al. 1990. "American oncology and the discourse on hope." Culture, Medicine and Psychiatry, 14(1): 59-79.

GRUDZINSKI, Roberta. 2013. A nossa batalha é fazer o governo trabalhar: estudo etnográfico acerca das práticas de governo de uma associação de pacientes. MA Dissertation - Postgraduate Program in Social Anthropology/UFRGS.

GUEDES, Cristiano; DINIZ, Debora. 2009. "A ética na história do aconselhamento genético: um desafio à educação médica." Revista Brasileira de Educação Médica, 33(2): 247-252.

JARDIM, Laura et al. 2001. "A survey of spinocerebellar ataxia in South Brazil - 66 new cases with Machado-Joseph disease, SCA7, SCA8, or unidentified disease-causing mutation.” Journal of Neurology, 248: 870-876.

KONRAD, Monica. 2003. "Predictive genetic testing and the making of the pre-symptomatic person: prognostic moralities amongst Huntington'saffected families." Anthropology and Medicine, 10(1): 23-49.

LIPPMAN, Abby. 1992. "Led (astray) by genetic maps: the cartography of the human genome and health care." Social Science and Medicine, 35(12): 1469-72.

LOCK, Margaret. 2008. "Biosociality and susceptibility genes: a cautionary tale". In: S. Gibbon and C. Novas (eds.), Biosocialities, genetics and the social sciences: making biologies and identities. New York: Routledge. pp. 56-78.

LOPES-CENDES, Iscia et al. 1997. "Molecular characteristic of the MachadoJoseph disease mutation in 25 newly described Brazilians families." Brazilian Journal of Genetics, 20: 717-724.

MATTINGLY, Cheryl. 2010. The paradox of hope: journeys through a clinical borderland. Berkeley and Los Angeles, California: University of California 
Press.

MENEZES, Rachel. 2013. "A medicalização da esperança: reflexões em torno de vida, saúde/doença e morte.” Amazônica-Revista de Antropologia (online), 5(2): 478-498.

MOL, Annemarie. 2008. The logic of care: health and the problem of patient choice. London and New York: Routledge.

NOVAS, Carlos. 2006. “The political economy of hope: patients' organization, science and biovalue." BioSocieties, 1: 289-305.

PETRYNA, Adriana. 2011. "Experimentalidade: ciência, capital e poder no mundo dos ensaios clínicos.” Horizontes Antropológicos, 17(35): 127-16o. . 2002. Life exposed: biological citizenship after Chernobyl.

Princeton, New Jersey: Princeton University Press.

RABEHARISOA, Vololona; MOREIRA, Tiago and AKRICH, Madeleine. 2013.

'Evidence-based activism: patients' organizations, users' and activist's groups in knowledge society." CSI Working Papers Series, 33: 1-25.

RABEHARISOA, Vololona et al. 2012. "The dynamics of causes and conditions. The rareness of diseases in French and Portuguese patients's organizations engagement in research." CSI Working Papers Series, 26: 1-39.

RABINOW, Paul. 1999. "Artificialidade e Iluminismo: da sociobiologia à biossociabilidade." In: Antropologia da razão. Rio de Janeiro: Relumé Dumara. pp. 135-157.

ROSE, Nikolas. 2013. A política da própria vida: biomedicina, poder e subjetividade no século XXI. São Paulo: Paulus.

SCHNEIDER, David. 1980. American kinship: a cultural account. Chicago: University of Chicago Press.

WALDBY, Catherine. 2002. "Stem cells, tissue cultures and the production of biovalue." Health: An Interdisciplinary Journal for the Social Study of Health, Illness and Medicine, 6(3): 305-23.

WEINER, Kate. 2011. "Exploring genetic responsibility for the self, family and kin in the case of hereditary raised cholesterol”. Social Science \& Medicine, 72(11): 1760-1767.

Waleska de Araújo Aureliano

Institute of Social Sciences, State University of Rio de Janeiro (UERJ) waurelianorio@gmail.com 